\title{
Livability Level As A Guideline Of Arrangement Of Suprapto Road City Walk Corridor In Bengkulu City
}

\author{
Rahzon Afryan ${ }^{1}$, M. Sani Roychansyah ${ }^{2}$ \\ 1 Student of the Master of Architecture, Department of Architecture and \\ Planning, Universitas Gajah Mada \\ 2 Lecturer of the Master of Architecture, Department of Architecture and \\ Planning, Universitas Gajah Mada
}

\author{
Article History \\ Received : 12 June 2019 \\ Accepted : 02 July 2019 \\ Published : 01 October 2019
}

\begin{abstract}
Livable road corridors are corridors designed to accommodate the needs of all road users (motorists, cyclists and pedestrians). Livable Street provides a balance of activity between vehicles using the road corridor and the different communities there. At this time, Suprapto Road is a road corridor with a function as a commercial area. The government's program to develop Suprapto Road in the future is by transforming it into a City Walk of Bengkulu City, this idea was stated by the Head of the Public Works and Housing Office of PUPR in Bengkulu, Mr. Rozy Ismawardi. The City Walk concept is not new, several places around the world have presented the City Walk concept in the corner of the city space, such as Clark Quay, Far East Square, and Orchard Road in Singapore. Through the City Walk concept, the local government can turn a dead old city into an active area. Related with the Bengkulu City government program above, a study is needed to get an idea of the level of livability if the city road in Bengkulu is used as a City Walk. Thus, it will objectify the factors that influence it while providing appropriate structuring guidelines for the City Walk that is Livable in Suprapto Street corridor. This study uses qualitative rationalistic methods through the perception of individuals in an effort to see, understand, and realize how the level of livability if a road functioned as a City Walk. This research begins with an observation activity on the condition of Suprapto Street in Bengkulu, complemented with the theory of livability and City Walk. Standard provisions and criteria are used to see what factors influence the level of livability in the road corridor. The research results will be the basis for determining the City Walk structuring arrangement for the Suprapto Street corridor.
\end{abstract}

Keywords: Livability, City Walk, Street's Space

\section{Introduction}

The starting point for the development of Bengkulu city is becoming a more developed and known area. The arrival of the British made Bengkulu even more crowded, especially after the construction of Fort Marlborough which was not far from the coast of Tapak Paderi. The British governed the placement of urban space based on their economic bases, namely shipping and trade. Bengkulu city center at that time was around Fort Malborough which was

Correspondence: Rahzon Afryan

Student of the Master of Architecture, Department of Architecture and Planning, Universitas Gajah Mada

E-mail: afryanrahzon@gmail.com
500 meters from the shore of Bengkulu bay. Since the arrival of the British to Bengkulu, large roads have been built to facilitate transportation. Gradually Bengkulu was also filled with immigrants from China, Bugis, Java, Madura, Malay, and others. One of the characteristics of an increasingly advanced region is the commencement of heterogeneity (plurality) of its population. The development of Bengkulu City is inseparable from the role of Chinese villages (Chinatown). Chinese villages are the economic wheel of Bengkulu city. Chinese villages were increasingly abandoned in the 2000s, the swallow's nest business became more widespread. One of the streets that became the center of trade was the intersection of five at the end of Suprapto Road, which was once just a city boundary 
where travelers stopped for resting. After that the area that appeared was only a jungle.

Figure 1. Map of Bengkulu City in 1960

Source: Marlborough Fortress Historical Document

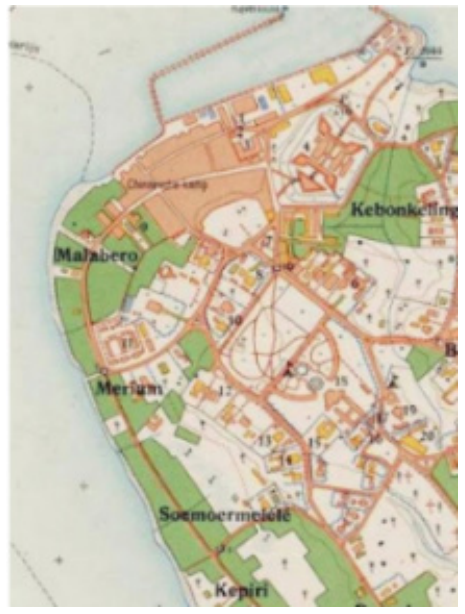

The development of the city was directed to the east and west ring roads which were built by the governor of Suprapto 3 (1979-1989 term). The two ring roads became the centers of the new economy. The entrepreneurs also transferred their business to that location. One of the regions developed by the Bengkulu government at that time was Suprapto Street. The name given for this road is pinned to commemorate the 3rd governor of Bengkulu, namely Lieutenant Suprapto.

Figure 2. Suprapto Road located next to Jamik Mosque at the time before it was used as a trade and service area. Source: Google

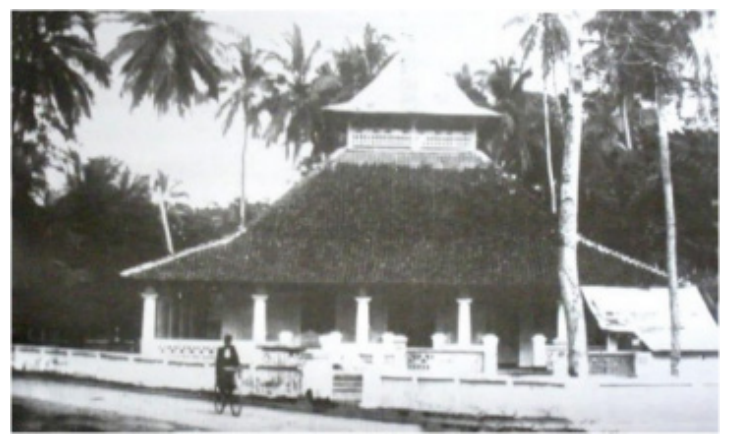

The physical side of this road has been built with a wide road that can support trading activities, in the 2000s this road was improved in terms of the addition of sidewalks and road medians.

Suprapto Street which functions as a trade and service area can be found in the Bengkulu City Spatial Plan (Bengkulu City RTRW 2012-2032) which states that along the Suprapto Road is intended for the informal sector. As well as trade and service centers are in the district of Ratu Samban consisting of Bengkulu Indah Mall (BIM), Mega Mall (MM), Modern Traditional Market (PTM), Suprapto Street, Pasar Minggu. Article 30 of the Bengkulu City Spatial Plan for 2012-2032 states that the infrastructure for the pedestrian road network and facilities, one of which is Suprapto Street.

On this road there are arcades and sidewalks as pedestrian paths for the people of Bengkulu to walk in this area. this street has parking on street along the road. But at that time Bengkulu people still often used public transportation to travel to Suprapto Street. Therefore, the vehicle parking lot was used by street vendors to sell their products. Activities in the walking path are still very comfortable and safe to pass by visitors

Figure 3. Pedestrian Path on Suprapto Street Source: Personal Documents

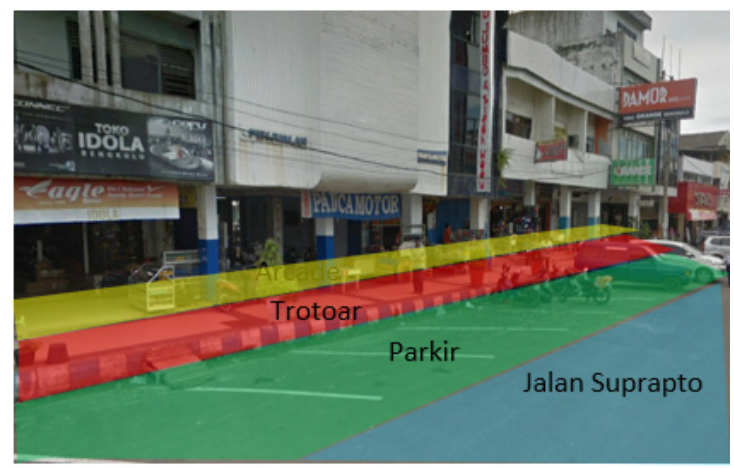

As the city of Bengkulu developed in 2009 the Bengkulu government established a new modern shopping center, Mega Mall and Bengkulu Indah Mall. This is enough to affect the Suprapto area because many residents find it more attractive to shop at the new shopping center that provides more comfortable needs and places of escape. in addition, Suprapto Road experienced a decrease in activity due to the considerable increase in traffic flow experienced by Bengkulu Province, due to the increasing number of motor vehicle growths of $\pm 15.04 \%$ per year (Anzy and Legowo, 2016). Decreased activity in this road space which causes street vendors who used to sell at vehicle parking locations can no longer do so. The curbing carried out by the Bengkulu city government resulted in the removal of street vendors. In response to this in 2015 the Bengkulu government revitalized the sidewalks and drainage canals on this road aimed at 
providing comfort for pedestrians and street vendors. However, these efforts have not yet to produce these results as seen from the still low usage of the sidewalk.

Figure 4. The condition of activities on the sidewalks of Suprapto Street after being revitalized by the Bengkulu city government still looks empty of users.

Source: Personal Documents

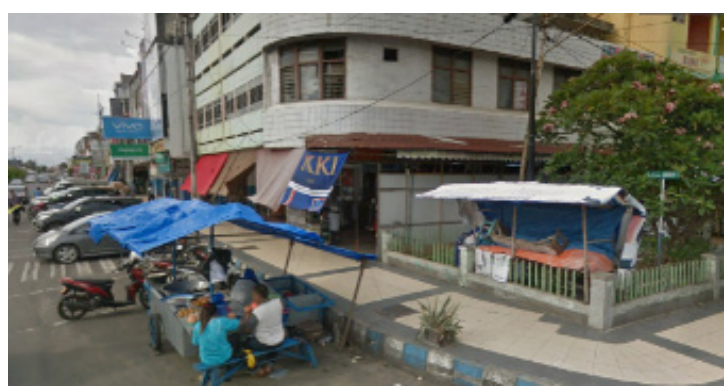

Not only that the Bengkulu government also created the Smart City Park on Suprapto Street which is located close to the Landmark of Bengkulu City.

Figure 5. Smart City Park located on Suprapto Road and close to Queen Samban Monument.

Source: Personal Documents

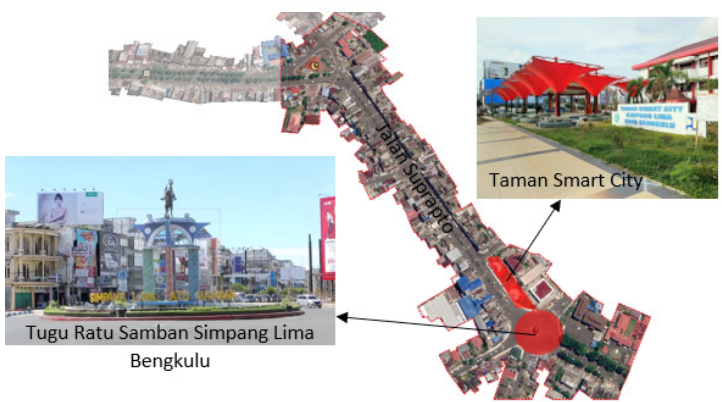

It aims to attract millennials generation to do activities there. The consideration is based on the data from BPS which states that Bengkulu residents are the most vulnerable from the age group of 20-24 years. This is also unlike the expectations of the city government as reported by one of the print media in the city of Bengkulu that the park is now empty of visitors and there is already a lot of wild grass. The Bengkulu government's efforts to improve the physical space of Suprapto Street in order to attract the attention of the Bengkulu Society to carry out activities there was considered unsuccessful, this was revealed by one of the Deputy Chairperson of the Bengkulu City DPRD Commission III, Rena Anggraini. Rena also said that the revitalization of the sidewalk seemed futile because there were still many violations carried out by street vendors and people who parked vehicles on the sidewalk. Based on the results of the initial interview conducted with Mr. Rozi Ismawardi as Head of Highways in Bengkulu PUPR Bengkulu City stated that "Suprapto Street will be used as City Walk of Bengkulu City for future development" (2019)

\section{Theory}

\section{Livability}

\section{Livable Street}

Jacobs (1995: 152) argues that urban roads are said to be successful when people come to appear at different times to times. Meanwhile, the total number of people who use the road at a time and how people spread and use their time (at different times) all day, are two different things (Jacob, $1995: 154)$. On the other hand, Mou-don (1987: 29) states that a lively and successful road requires a balanced mixing between different user groups (different user groups) and different activities (different activities). According to Appleyard (1981) livable street is a road environment that is designed to accommodate the needs of each user. Including drivers, public vehicles, bicycles, and pedestrians both with disabilities, elderly, and children. The number of travel routes is usually kept to a minimum for safety crossing.

\section{Livability and Public Social Life}

The attraction of city livability lies in anticipating stimulating experiences in the public realm that contributes to positive mental, emotional and physical health. Therefore, city livability is affected by opportunities that enable meaningful social exchange that helps to build a sense of belonging and community pride as residents of the place. Social welfare and psychological health depend on the community (Oldenberg, 1989 in Choudhury, 2008) 
Table 1. Livability of public social life

Source : Litman, Todd Alexander, 'Economic Value of Walkability', Transportation research record 1828_3, Paper No. 03-2731 in Choudhury, 2008.

\begin{tabular}{lll}
\hline No & Quality & Description \\
\hline 1 & Safety and Health & $\begin{array}{l}\text { Traffic safety, personal } \\
\text { security and public } \\
\text { health }\end{array}$ \\
2 & $\begin{array}{l}\text { Quality of the local } \\
\text { environment }\end{array}$ & $\begin{array}{l}\text { Cleanliness, Noise, Wa- } \\
\text { ter Quality, Air Quality }\end{array}$ \\
3 & $\begin{array}{l}\text { Relationship between } \\
1 \text { neighboring } \\
\text { community }\end{array}$ & $\begin{array}{l}\text { Respect for each other, } \\
\text { community identity }\end{array}$ \\
4 & $\begin{array}{l}\text { Opportunities for } \\
\text { recreation and } \\
\text { entertainment }\end{array}$ & - \\
5 & $\begin{array}{l}\text { Aesthetics } \\
\text { The existence of a } \\
\text { cultural historical } \\
\text { structure }\end{array}$ & $\begin{array}{l}\text { Aged trees, traditional } \\
\text { architectural style, } \\
\text { environmental } \\
\text { resources. }\end{array}$
\end{tabular}

\section{Citywalk}

\section{Definisi Citywalk}

City Walk literally consists of 2 words, city and walk. City means city or within the city, while walk means path or road. Generally, city walk means pedestrian path in the city. The path can be formed due to a row of buildings or landscaping in the form of plants, City walk is a pedestrian path with complete shopping facilities, and is managed by a business developer, so that it can survive and develop. City walk as a path for pedestrians in urban design terminology including path, which connects a node (can be a public facility, or a traffic mode node), the nearest district (in the form of a region). A maximum of every $300 \mathrm{~m}$ distance must be a temporary stop for pedestrians. In its realization, City Walk is divided into three types of city walk implementation systems, namely Outdoor, indoor and semi-outdoor.

According to Aditya W. Fitrianto in the 2006 IAI article, city walk is nothing more than a road corridor devoted to a row of shops. By default, these roads are located on property owned by private developers or their management can be said to be under one roof and the roads are designated as public spaces. City walk is a public area according to Scrutton (in Beng Huat and Edwards, 1992) is a place that is designed, at least everyone can have accessibility to it, users in it are not excluded and the behavior of each user towards other users follow the general norms of community decency. According to Rossi (Rossi, 1992), public space is the share of the city, because the city is a human being, the city is the product of culture.

\section{City Walk Elements}

From the understanding of the City walk concept above, conclusions can be drawn regarding the main elements that form the City walk, including Street Space, pedestrian, and retails (buildings).

The building on the city walk concept is one of the elements forming a city walk in a modern shopping center. Because of its function as a commercial place, the building must exist to fulfill the commercial function of this modern shopping center. (Booth, Norman. K, 1983).

In the Portland Pedestrian Design Guide (1998; A-5), the pedestrian zone is divided into 4 zones, namely Curb Zone, Furnishings Zone, Through Pedestrian Zone, and Frontage Zone.

\section{Theory Dialogue}

In determining the level of livability in the road space that will be functioned as a City Walk, the theory above in this study requires a theoretical dialogue between livability theory and City Walk theory. From the theories above, the relationship between livability and City Walk can be drawn as follows:

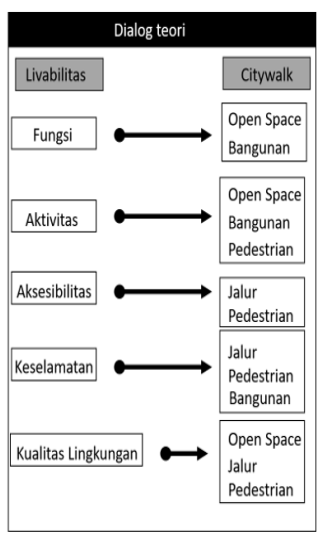

\section{Method}

\section{Research Approach}

This qualitative research method consists of 
rationalistic and positivistic while quantitative research method consists of phenomena and rationalistic, the process of analysis can be deductive or inductive. The deductive process departs from things that are general in nature, then conclusions are made of a specific nature, while the inductive analysis process departs from things that are specific, to then be made conclusions that are general (Muhadjir, 1998).

This study uses a qualitative rationalistic method which is a method that focuses on rationalism, namely the perception of individuals in seeing, understanding and realizing how the influence of physical settings on activities in arranging the Livable City Walk Bengkulu in the corridor of Suprapto street. This research begins with field observations or direct observations of the existing Suprapto road corridor conditions based on Parameters, Variables, SubVariables, and indicators in the literature review. The standards and criteria are used to see what factors can be utilized for Livable City Walk of Suprapto street. While the process of analysis in this study uses deductive where the results of the research in the research matrix are linked to draw conclusions.
The instrument is a tool used to answer research questions. The research instruments are Variable, Indicators, Parameters and Matrices. Variables are concepts based on textual references/theories. Indicators are things that are part of the parameters based on the reference/theory. Parameter is measured values, based on references. The determination process is as follows: (Table 2 and Table 3 ).

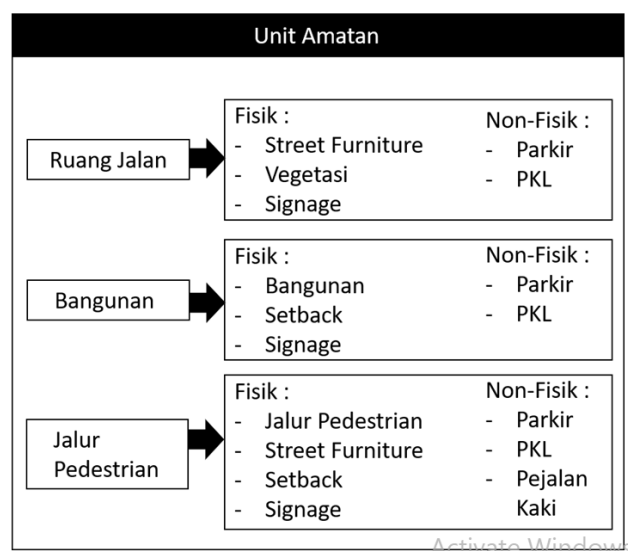

The following is the basis for determining the level of livability based on the theory that was previously set: (Table 4)

Table 2. Research Instruments

\begin{tabular}{|c|c|c|c|c|}
\hline No & Variable & Indicator & Parameter & Aspect \\
\hline \multirow[t]{2}{*}{1} & \multirow[t]{2}{*}{ Function } & \multirow{2}{*}{$\begin{array}{l}\text { Function of } \\
\text { Building and } \\
\text { public open } \\
\text { space }\end{array}$} & a. Types and functions of buildings & Physical \\
\hline & & & b. Type and Number of RTP functions & Physical \\
\hline \multirow[t]{2}{*}{2} & \multirow[t]{2}{*}{ Activity } & \multirow[t]{2}{*}{$\begin{array}{l}\text { Social Activities } \\
\text { (non-movement) }\end{array}$} & $\begin{array}{l}\text { a. Types of Activities and composition of types of road } \\
\text { users based on non-movement activities }\end{array}$ & Non physical \\
\hline & & & $\begin{array}{l}\text { b. Location, Time, Frequency of non-movement } \\
\text { activities }\end{array}$ & Non physical \\
\hline \multirow[t]{4}{*}{3} & \multirow[t]{4}{*}{ Accessibility } & \multirow[t]{4}{*}{ Accessibility } & The range and spatial conditions of circulation & Physical \\
\hline & & & b. Types and composition of road users by mode & Non physical \\
\hline & & & c. Types and range of services for parking activities & Non physical \\
\hline & & & d. Location, Time, Frequency of movement activity & Non physical \\
\hline \multirow[t]{2}{*}{4} & \multirow[t]{2}{*}{ Security } & \multirow[t]{2}{*}{ Traffic Conflict } & a. Types and amounts of traffic conflicts & Non physical \\
\hline & & & b. Location and Time of the traffic conflict & Non physical \\
\hline \multirow[t]{2}{*}{5} & \multirow{2}{*}{$\begin{array}{l}\text { Environmen- } \\
\text { tal quality }\end{array}$} & \multirow[t]{2}{*}{ RTH quality } & a. Green Open Conditions & Physical \\
\hline & & & b. RTH utilization activities & Non physical \\
\hline
\end{tabular}


Table 3. City Walk Criteria Are Livable

\begin{tabular}{lll}
\hline Aspect & Component & Indicator \\
\hline Function & Building & The diversity of building functions that support the Vitality of the Area \\
& Open Space & The quality of open space that has facilities to support social interaction \\
Activity & Building & Has a large capacity and free parking lot in front of the building \\
& Pedestrian Path & $\begin{array}{l}\text { Availability of street furniture, signage as a clear marker, and available } \\
\text { pedestrian paths }\end{array}$ \\
& Open Space & Street Furniture availability \\
Accessibility & Pedestrian & Quality Connectors and Street Furniture \\
Safety & Building & Setback \\
& Pedestrian Path & Traffic conflict \\
Environmental Quality & Building & Greening \\
& Open Space & Vegetation
\end{tabular}

Table 4. Determination of Livability Level Based on Livability Theory for evaluating the results of observations and questionnaires

\begin{tabular}{|c|c|c|c|}
\hline \multirow[t]{6}{*}{ Function } & \multirow[t]{3}{*}{$\begin{array}{l}\text { Building } \\
\text { Functions }\end{array}$} & High Livability Level & $\begin{array}{l}\text { There are Commercial, Residential and Public facili- } \\
\text { ties Functions along the built road }\end{array}$ \\
\hline & & Moderate Livability & $\begin{array}{l}\text { There are commercial and residential functions with } \\
\text { limited land on most of the developed land }\end{array}$ \\
\hline & & Low livability level & $\begin{array}{l}\text { There is a Commercial / residential / Public facilities } \\
\text { function with a narrow and single land }\end{array}$ \\
\hline & \multirow[t]{3}{*}{$\begin{array}{l}\text { Open Space } \\
\text { Function }\end{array}$} & High Livability Level & $\begin{array}{l}\text { Functioned as an entertainment stage and building } \\
\text { mass liaison. }\end{array}$ \\
\hline & & Moderate Livability & $\begin{array}{l}\text { Functioned as an entertainment stage or building } \\
\text { mass liaison }\end{array}$ \\
\hline & & Low livability level & Not functioning and not maintained \\
\hline \multirow[t]{6}{*}{ Activity } & \multirow{3}{*}{$\begin{array}{l}\text { Activity time } \\
\text { Road users } \\
\text { Accessibility }\end{array}$} & High Livability Level & $\begin{array}{l}\text { There are } 3 \text { different activity times namely Morning, } \\
\text { Afternoon, Night with busy intensity }\end{array}$ \\
\hline & & Moderate Livability & $\begin{array}{l}\text { There are } 3 \text { different activity times: morning, after- } \\
\text { noon, evening with moderate intensity }\end{array}$ \\
\hline & & Low livability level & $\begin{array}{l}\text { There are } 3 \text { different activity times: morning, after- } \\
\text { noon, evening with a little intensity }\end{array}$ \\
\hline & \multirow{3}{*}{$\begin{array}{l}\text { Traffic Conflict } \\
\text { Activity time }\end{array}$} & High Livability Level & $\begin{array}{l}\text { There are } 3 \text { categories of road users, namely Passer- } \\
\text { by, Visitor, and Resident }\end{array}$ \\
\hline & & Moderate Livability & There are only 2 Road Users \\
\hline & & Low livability level & There are 1 category of road users only \\
\hline \multirow[t]{3}{*}{ Accessibility } & \multirow{3}{*}{$\begin{array}{l}\text { Road users } \\
\text { Accessibility } \\
\text { Traffic Conflict }\end{array}$} & High Livability Level & $\begin{array}{l}\text { Facilitated by a pedestrian path complete with street } \\
\text { furniture and has an extensive setback }\end{array}$ \\
\hline & & Moderate Livabilily & $\begin{array}{l}\text { It is facilitated by the pedestrian path and has a set- } \\
\text { back that is not proportioned }\end{array}$ \\
\hline & & Low livability level & There is no pedestrian path and no setback. \\
\hline \multirow[t]{3}{*}{ Safety } & RTH quality & High Livability Level & There is no traffic conflict \\
\hline & \multirow{2}{*}{$\begin{array}{l}\text { Activity time } \\
\text { Road users }\end{array}$} & Moderate Livability & $\begin{array}{l}\text { There are traffic conflicts at several points and do not } \\
\text { disturb road users }\end{array}$ \\
\hline & & Low livability level & Traffic conflicts occur and disrupt road users \\
\hline \multirow{3}{*}{$\begin{array}{l}\text { Environmental } \\
\text { Quality }\end{array}$} & \multirow[t]{3}{*}{ Accessibility } & High Livability Level & Maintained, has street furniture and vegetation \\
\hline & & Moderate Livability & Maintained, lacking street furniture and vegetation \\
\hline & & Low livability level & $\begin{array}{l}\text { Not maintained and there is no street furniture and } \\
\text { vegetation }\end{array}$ \\
\hline
\end{tabular}


Armed with related theories and respondent information and area conditions related to predetermined livability variables, all of them are related to find findings of factors that influence Livable City Walk on Suprapto street, Bengkulu.

The findings of the Livable City Walk influence factor are discussed to see facts in the field and the findings of research on existing theories. The results are expected to strengthen the livable City Walk research findings in the Suprapto Bengkulu corridor. Findings Factors affecting livable City Walks, existing regional problems (from the results of livability conditions analysis) are low as priority design recommendations.

\section{Analysis and Discussion}

\section{Suprapto Street Criteria as City walk}

In analyzing the Suprapto Road if functioned as a City Walk using the City Walk criteria table that has been explained in chapter 2 above. The criteria that must be met in applying the City Walk concept :

1. The street to the amusement and mass unification of buildings at the intersection

2. Have a Pedestrian Trail along the Corridor

3. Building Pattern

From the 3 criteria above, an analysis can be carried out on Suprapto Street, following analysis by the researcher:

1. The Function of Road Spaces for Entertainment Stage and Mass Integration of Buildings at Intersections.

Based on the results of field surveys and field observations that Suprapto Street has open space at 3 points, namely at the intersection of K.H Abidin street and in front of the Telkom Office. The first open space at the intersection of K.H Abidin street in the form of green open space that looks not well ordered and not functioned properly. As for the open space in front of the Telkom office in the form of a smart city park that was built by the city government as a public open space that is well organized in order to accommodate social activities.

2. Have Pedestrian Trails Along the Corridor Based on the results of surveys and field observations that Suprapto street has a pedestrian path, but there are some parts that are still cut off. Some parts along
Suprapto street pedestrian path are also heavily functioned by the sidewalk seller and shopkeepers to put their wares. This makes the pedestrian lane experience the transfer carried out by street vendors and shop owners, making it inconvenience for the pedestrian lane users on Suprapto street.

Figure 6. Pedestrian Line on Suprapto Street.

Source: Researcher Analysis 2019

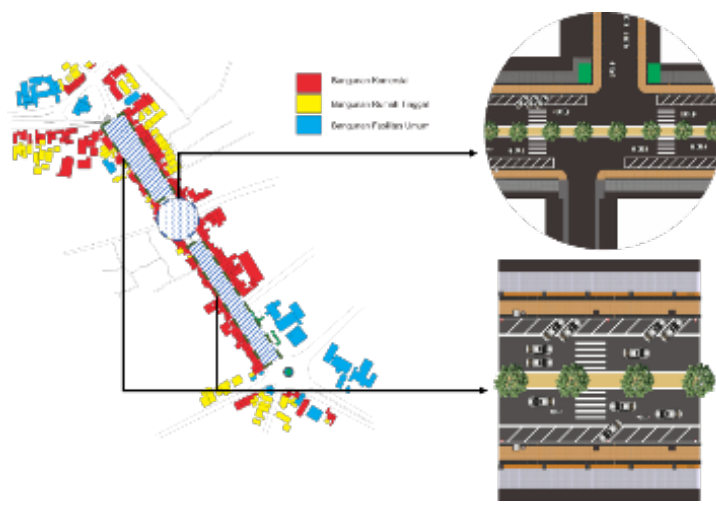

Based on the results of surveys and observations, the road already has a pedestrian zone consisting of 4 zones including Crub Zone, Furnishings Zone, Trough Zone, and Frontage Zone. This has fulfilled the criteria needed in implementing the City Walk Concept. The following is the Pedestrian Zone that already exists on Suprapto Street:

Figure 7. Pedestrian Line Zone that exists today Source: Researcher Analysis 2019
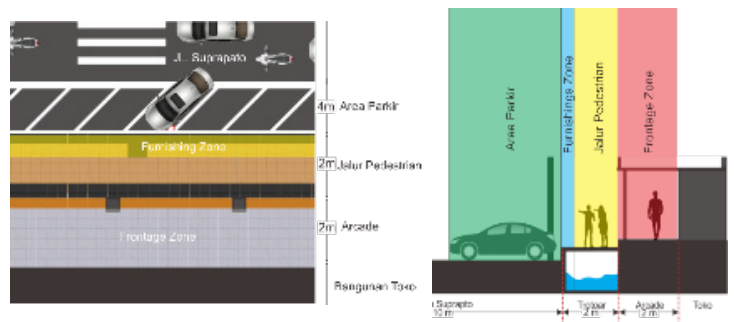

Figure 8. Pedestrian Path Zone that is on the node Source: Author Analysis 2019

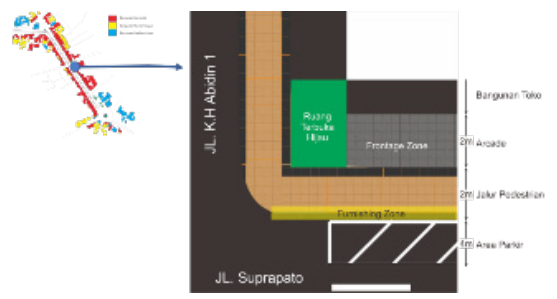

3. Building Pattern

Based on the results of surveys and field measurements, the building pattern is oriented towards facing the road and has 
a linear building pattern, following the orientation of the building and the linear building pattern that exists on Suprapto Street.

Figure 9. Condition of building orientation on Suprapto Street

Source: Researcher Analysis 2019

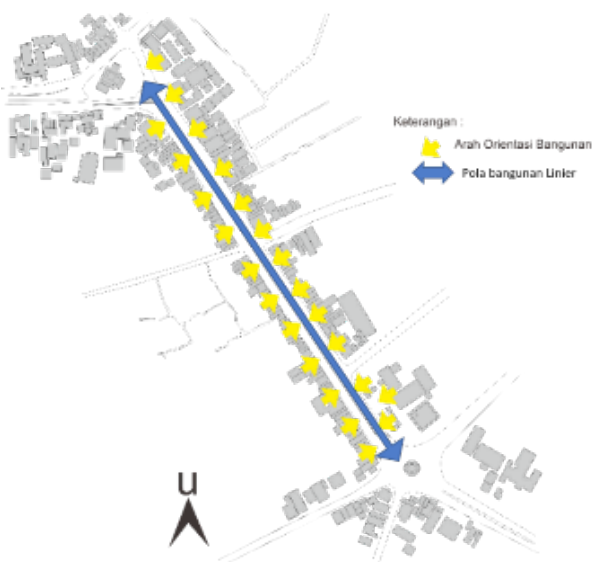

Based on the observations above, Suprapto street already has 2 City Walk elements that have been fulfilled, namely the Pedestrian Path and Building, while the criteria for the Open Space Function have not been fulfilled because open space is not maintained and is not functioning as an entertainment stage and building mass connector. To fulfill this matter, an open space arrangement is required with criteria as a stage for connecting the building mass.

\section{Livability Conditions of Suprapto Road Based on Observation}

Table 5. Observation Results and Findings on the Suprapto Road Livability Conditions

\begin{tabular}{llccc}
\hline Variable & Sub-Variables & \multicolumn{3}{c}{ Livability Value Weight } \\
& & Season 1 & Season 2 & Season 3 \\
\hline Function & $\begin{array}{l}\text { Building } \\
\text { Function } \\
\text { Existence of } \\
\text { Public Open } \\
\text { Space }\end{array}$ & 0 & 0 & 0 \\
Activity & Activity time & 0 & 0 & 0 \\
Accessibility & Generator & 0 & 0 & 0 \\
Safety & Road users & 0 & 0 & 0 \\
Environmental & Accessibility & 0 & 0 & 0 \\
quality & & 0 & 0 & 0 \\
Livability Conditions & & &
\end{tabular}

\begin{tabular}{|c|c|c|c|}
\hline Variable & Sub-Variable & Discussion & Level Livability \\
\hline Function & $\begin{array}{l}\text { Building } \\
\text { Function }\end{array}$ & $\begin{array}{l}\text { The building functions on Suprapto Street are dominated by commercial buildings with } 85 \\
\text { blocks, but along Suprapto street the building functions are quite diverse such as mixuse } \\
\text { there are } 49 \text { blocks, public facilities } 10 \text { Blocks, Empty Building } 8 \text { blocks and Green open } \\
\text { space there are } 3 \text { areas. From this result livability conditions for diversity are included in the } \\
\text { high category. }\end{array}$ & Hight \\
\hline \multirow[t]{3}{*}{ Activity } & $\begin{array}{l}\text { Existence of } \\
\text { Public Open } \\
\text { Space }\end{array}$ & $\begin{array}{l}\text { Public open space on Suprapto street is only found on the section of road } 3 \text { which is the } \\
\text { smart city park, this shows that the livability conditions for public spaces are of low category. }\end{array}$ & ○ Low \\
\hline & Activity time & $\begin{array}{l}\text { For the time of activity on Suprapto street is not active } 24 \text { hours, there are only certain times, } \\
\text { the active time from 10:00 to } 22: 00 \text { means that there are only } 12 \text { hours of activity time that } \\
\text { occurs on Suprapto street, this shows that the livability conditions for the activity time are } \\
\text { included in medium category. }\end{array}$ & Medium \\
\hline & Generator & $\begin{array}{l}\text { There are quite a variety of generators owned by Suprapto street, it has generators as } \\
\text { commercial areas. Apart from that, each part has a generator namely part } 1 \text {, there is a plural } \\
\text { mosque and a row of commercial buildings that sell daily necessities, part } 2 \text { has a row of } \\
\text { commercial buildings that sell a variety of daily necessities, and part } 3 \text { has a public open } \\
\text { space and a row commercial buildings that sell daily necessities. }\end{array}$ & Medium \\
\hline Accessibility & Road users & $\begin{array}{l}\text { Road user activity based on observations has the highest passer-by road user activity from } \\
\text { day to night, but visitors and residents only occur during the evening and night. This shows } \\
\text { that livability conditions for Road user activities are in the medium category. }\end{array}$ & Medium \\
\hline Safety & Accessibility & $\begin{array}{l}\text { Access to reach the destination on Suprapto street is quite easy because it is located in the } \\
\text { center of the city but access to the area is still lacking this is indicated by the lack of capacity } \\
\text { and dimensions of vehicle parking along Suprapto street. this shows that livability conditions } \\
\text { for accessibility are in the medium category. }\end{array}$ & $\bigcirc$ Low \\
\hline \multirow[t]{2}{*}{$\begin{array}{l}\text { Environmental } \\
\text { quality }\end{array}$} & Traffic Conflict & $\begin{array}{l}\text { Traffic conflict on Jalan Suprapto is still dominated by a lot of merchandise and street vendors } \\
\text { who use pedestrian paths, and also traffic jams at certain hours, this is also influenced by the } \\
\text { entry and exit of vehicles into the parking lot. This shows that the livability conditions for traffic } \\
\text { conflicts are in the low category. }\end{array}$ & $\bigcirc$ Low \\
\hline & $\begin{array}{l}\text { Quality of green } \\
\text { open spaces }\end{array}$ & $\begin{array}{l}\text { The quality of green open spaces is still deficient because there are no green lines in the } \\
\text { pedestrian pathway, and there are green open spaces that do not function properly, this } \\
\text { shows that the livability conditions for the quality of green open spaces are in a Low category }\end{array}$ & $\bigcirc$ Low \\
\hline
\end{tabular}


Roadblock 1 and roadblock 3 have a fairly good level of livability compared to roadblock 2 , this shows that roadblock 1 has a livability condition in terms of function and activity and accessibility and safety for environmental quality is still low, for environmental service road 3 has moderate livability conditions on functions and activities and environmental quality is low for accessibility and safety, and for section 2 Road has low livability conditions on accessibility and environmental quality while for functions and activities the level of livability is moderate.

\section{Livability Conditions Based Questionnaire}

(Table 6)

This high livability shows that the diversity of building functions on Surpapto street makes various activities carried out by Road users to do activities on Suprapto Street. The highest activity carried out is looking for daily needs. Besides that, the level of passing the Suprapto Road to reach the destination in the Suprapto area and the destination outside the Surpapto Road is still quite high. Accessibility and safety have low value. Based on the results of the questionnaire above, the modes of transportation used by respondents in achieving their objectives in the Surpapto area are quite diverse. This shows that access in reaching the Suprapto area from outside the area is quite easy. However, access in the area is still not good, it is shown that there are still some traffic conflicts and the lack of a special path for cyclists, pedicabs and pedestrians in the area, which makes the level of livability in the area still low. Environmental quality has a low value. Based on the results of the questionnaire above, the shade, noise, and odor on Suprapto street still has an unfavorable value.

Table 6. Results of Questionnaires and Interviews

\begin{tabular}{|c|c|c|c|c|c|c|c|}
\hline \multirow[t]{2}{*}{ Variable } & \multirow{2}{*}{\multicolumn{2}{|c|}{ Questions }} & \multicolumn{4}{|c|}{$\begin{array}{l}\text { Assessment weighting of } \\
\text { answers }\end{array}$} & \multirow{2}{*}{$\begin{array}{c}\text { Level } \\
\text { Livability }\end{array}$} \\
\hline & & & A & $\mathrm{B}$ & $\mathrm{C}$ & $\mathrm{D}$ & \\
\hline Function & 1. & $\begin{array}{l}\text { Where do you often visit Suprapto } \\
\text { Street? }\end{array}$ & 20 & 27 & 0 & 96 & High \\
\hline \multirow[t]{2}{*}{ Activity } & 2. & $\begin{array}{l}\text { Why did you choose to do activities on } \\
\text { Suprapto Street? }\end{array}$ & 79 & 13 & 32 & 26 & Low \\
\hline & 3. & $\begin{array}{l}\text { How often do you pass Suprapto } \\
\text { Street? }\end{array}$ & 61 & 25 & 40 & 24 & Low \\
\hline \multirow[t]{5}{*}{ Accessibility } & 4. & $\begin{array}{l}\text { What vehicle do you use most often to } \\
\text { do your activities on Suprapto Street? } \\
\text { (can choose more than } 1 \text { answer) }\end{array}$ & 6 & 15 & 102 & 62 & Medium \\
\hline & 5. & $\begin{array}{l}\text { Currently there are only lanes for } \\
\text { motorized vehicles. Do you need spe- } \\
\text { cial lanes for bicycles, pedicabs and } \\
\text { pedestrians? }\end{array}$ & 94 & 43 & 10 & 3 & Low \\
\hline & 6. & $\begin{array}{l}\text { Are parking spaces on Suprapto Street } \\
\text { sufficient? }\end{array}$ & 44 & 57 & 48 & 1 & Low \\
\hline & 7. & $\begin{array}{l}\text { What do you think of the current } \\
\text { parking lot? }\end{array}$ & 18 & 62 & 70 & 0 & Medium \\
\hline & 8. & $\begin{array}{l}\text { Does a parking lot need to be made a } \\
\text { special place? }\end{array}$ & 85 & 44 & 17 & 4 & Low \\
\hline \multirow[t]{2}{*}{ Vehicle } & 9. & $\begin{array}{l}\text { Do you think the signs, street signs, } \\
\text { information boards in the Suprapto } \\
\text { Street environment are clear and help } \\
\text { you get to the destination? }\end{array}$ & 20 & 56 & 69 & 5 & Medium \\
\hline & 10. & $\begin{array}{l}\text { What traffic conflicts on Suprapto } \\
\text { Street bother you? }\end{array}$ & 60 & 48 & 19 & 22 & Low \\
\hline \multirow{3}{*}{$\begin{array}{l}\text { Environmental } \\
\text { quality }\end{array}$} & 11. & Is Suprapto Street already shady? & 68 & 62 & 20 & 0 & Low \\
\hline & 12. & $\begin{array}{l}\text { Do you feel noisy when on Suprapto } \\
\text { Street? }\end{array}$ & 14 & 94 & 28 & 14 & Low \\
\hline & & $\begin{array}{l}\text { Do you smell bad when on Suprapto } \\
\text { Street? }\end{array}$ & 13 & 66 & 36 & 35 & Low \\
\hline
\end{tabular}




\section{Factors That Influence the Livability of Suprapto Road}

Table 7. Discussion of Physical and Non-Physical Aspects

\begin{tabular}{|c|c|}
\hline & ROADBLOCK 1 \\
\hline BUILDING & $\begin{array}{l}\text { The diversity of building functions on this } \\
\text { section is quite diverse, with a medium height } \\
\text { of 2-4 floors, and has a modern building style. }\end{array}$ \\
\hline SETBACK & $\begin{array}{l}\text { In this section of the road the building setback } \\
\text { is good with a broad setback dimension and } \\
\text { regular harmony }\end{array}$ \\
\hline SIGNAGE & $\begin{array}{l}\text { Signage on the road section is quite clear as } \\
\text { the identity of each building, but there are still } \\
\text { some signage that intervene with the building } \\
\text { facade }\end{array}$ \\
\hline STREET FURNITURE & $\begin{array}{l}\text { In this section of road, there is still a lack } \\
\text { of street furniture because there are only } 3 \\
\text { electricity poles for street lighting }\end{array}$ \\
\hline VEGETATION & $\begin{array}{l}\text { Cut this road is still lacking vegetation because } \\
\text { there is only } 1 \text { palm tree plant as a barrier with } \\
\text { irregular spacing. }\end{array}$ \\
\hline PEDESTRIAN PATH & $\begin{array}{l}\text { The pedestrian lane on the section of the road } \\
\text { is good enough but there are some buildings } \\
\text { that do not have a flat, well-maintained } \\
\text { pedestrian lane on the east side of the road. }\end{array}$ \\
\hline STREET VENDORS & $\begin{array}{l}\text { In this section, there are still street vendors in } \\
\text { the section of road } 1 \text { east side totaling } 2 \text { street } \\
\text { vendors. }\end{array}$ \\
\hline PARKING & $\begin{array}{l}\text { At this section of the road there is still less } \\
\text { parking space due to the small dimensions of } \\
\text { the parking lot and the slight intensity. }\end{array}$ \\
\hline PEDESTRIAN & $\begin{array}{l}\text { In this section of the road, pedestrians are } \\
\text { still low because there is still little pedestrian } \\
\text { intensity. }\end{array}$ \\
\hline \multirow[t]{2}{*}{$\begin{array}{l}\text { TRANSPORTATION } \\
\text { USER }\end{array}$} & $\begin{array}{l}\text { In this section, vehicle users are quite diverse } \\
\text { and dominated by motorized vehicles }\end{array}$ \\
\hline & ROADBLOCK 2 \\
\hline BUILDING & $\begin{array}{l}\text { The diversity of building functions on this } \\
\text { section is quite diverse, with a medium height of } \\
2-4 \text { floors, and has a modern building style. }\end{array}$ \\
\hline SETBACK & $\begin{array}{l}\text { In this section of the road the building setback } \\
\text { is good with a broad setback dimension and } \\
\text { regular harmony }\end{array}$ \\
\hline SIGNAGE & $\begin{array}{l}\text { Signage on the road section is quite clear as } \\
\text { the identity of each building, but there are still } \\
\text { some signage that intervenes in the building } \\
\text { facade }\end{array}$ \\
\hline STREET FURNITURE & $\begin{array}{l}\text { In this section of the road there is no street } \\
\text { furniture }\end{array}$ \\
\hline VEGETATION & $\begin{array}{l}\text { This road cut is still lacking vegetation because } \\
\text { it is only found in open green space with } 2 \text { waru } \\
\text { trees that function as a barrier with an irregular } \\
\text { position which is located on the road section } 2 \\
\text { east side while for the west side there are only } \\
7 \text { small trees that function as directors. }\end{array}$ \\
\hline PEDESTRIAN PATH & $\begin{array}{l}\text { The pedestrian path on this section is good } \\
\text { because it is available along the road in a flat } \\
\text { and well-maintained condition }\end{array}$ \\
\hline STREET VENDORS & $\begin{array}{l}\text { In this section of the road there are } 13 \text { street } \\
\text { vendors who sell using sidewalks so that it } \\
\text { disturbs pedestrians. }\end{array}$ \\
\hline PARKING & $\begin{array}{l}\text { At this section of the road there is still less } \\
\text { parking space due to the small dimensions of } \\
\text { the parking lot and the slight intensity. }\end{array}$ \\
\hline PEDESTRIAN & $\begin{array}{l}\text { In this section of the road, pedestrians are } \\
\text { still low because there is still little pedestrian } \\
\text { intensity. }\end{array}$ \\
\hline $\begin{array}{l}\text { TRANSPORTATION } \\
\text { USER }\end{array}$ & $\begin{array}{l}\text { In this section, vehicle users are quite diverse } \\
\text { and dominated by motorized vehicles }\end{array}$ \\
\hline
\end{tabular}

\section{ROADBLOCK 3}

The diversity of building functions on this section is quite diverse, with a medium heigh of 2-4 floors, and has a modern building style.

SETBACK

In this section of the road the building setback is good with a broad setback dimension and regular harmony

SIGNAGE

Signage on the road section is quite clear as the identity of each building, but there are still some signage that intervenes in the building facade

STREET FURNITURE In this section of the street there is a complete street furniture on the east side of Smart City Park. But there is no street furniture on the west side of the road.

VEGETATION

On this section of the road there are diverse vegetation, namely hibiscus trees, pine trees, and bonsai. This vegetation serves as a guide and barrier so it is quite comfortable for activities in the Smart City Park.

PEDESTRIAN PATH The pedestrian path on this section is good because it is available along the road in a flat and well-maintained condition

STREET VENDORS On this section of the road there are 2 street vendors who sell using sidewalks so that it disturbs pedestrians.

PARKING

At this section of the road there is still less parking space due to the small dimensions of the parking lot and the slight intensity.

PEDESTRIAN In this section of the road, pedestrians are still low because there is still little pedestrian intensity.

TRANSPORTATION In this section, vehicle users are quite diverse USER and dominated by motorized vehicles

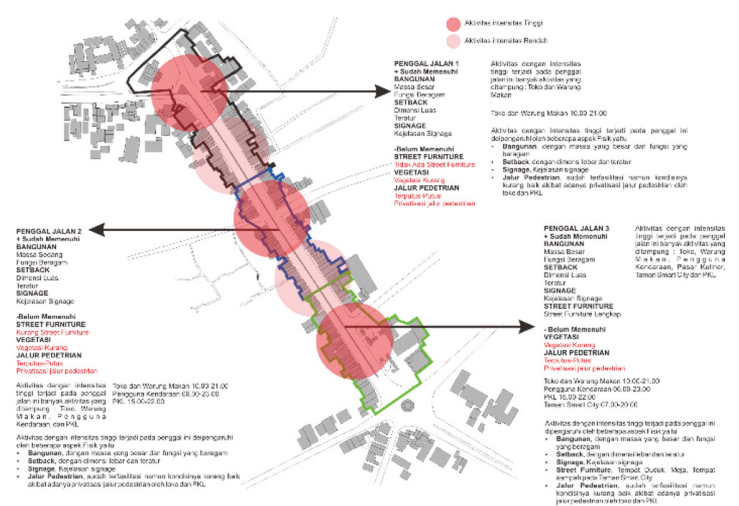

From the results above the factors that influence the high intensity of activities in the Suprapto Road corridor are buildings, setbacks, signage, and vegetation. While the physical aspects that need to be improved to improve livability are pedestrian paths, street funiture and vegetation.

\section{Findings and Discussion}

Based on the observations above, Suprapto street already has 1 City Walk criteria that are met, namely Buildings, while the Open Space and Pedestrian criteria have not been fulfilled because open space is not maintained and does not function as an entertainment stage and the 
connecting mass of buildings, meanwhile the pedestrian path are not yet available. To fulfill this matter, an open space arrangement with criteria as entertainment stage and building mass connector is needed. (Table 8)

Table 9. Livability Conditions of Suprapto Road

\begin{tabular}{|c|c|c|}
\hline Aspect & $\begin{array}{l}\text { Livability } \\
\text { level }\end{array}$ & Information \\
\hline Function & intermediate & $\begin{array}{l}\text { Vitality The diversity } \\
\text { of building functions } \\
\text { in the area }\end{array}$ \\
\hline Activity & intermediate & $\begin{array}{l}\text { Has a clear signage, } \\
\text { and pedestrian paths } \\
\text { are available, } 1 \text { open } \\
\text { space already has } \\
\text { Street Furniture. }\end{array}$ \\
\hline Accessibility & Low & $\begin{array}{l}\text { Pedestrian path is still } \\
\text { disjointed and do not } \\
\text { have street furniture }\end{array}$ \\
\hline Safety & Low & $\begin{array}{l}\text { Misuse of land by } \\
\text { street vendors and } \\
\text { vehicle parking }\end{array}$ \\
\hline $\begin{array}{l}\text { Environmental } \\
\text { quality }\end{array}$ & Low & $\begin{array}{l}\text { Vegetation is still } \\
\text { lacking }\end{array}$ \\
\hline
\end{tabular}

Based on the findings above, it is found that the condition of suprapto road livability is still low because of the 5 aspects there are only 2 aspects that already have a moderate level of livability in Suprapto Street. Functions and Activities, due to the diversity of building functions, having clear signage, and available routes. While the other 3 aspects are still low.

\section{Dialogue on Findings with Theories}

\section{(Table 10)}

Based on the table above it is known that, the aspect of function with the most important building component in Livable City Walk, for the aspect of activity with the pedestrian path component is quite important but there is still a shortage, namely the unavailability of street furniture, and for the safety aspect with building components play an important role because they have a wide setback. Whereas aspects and components that are still lacking a role will be a prioritize in recommending directions for Livable City Walk structuring.

Table 8. Findings and Discussion

\begin{tabular}{|c|c|c|c|}
\hline Variable & Existing & Questionnaires & Discussion \\
\hline Function & & & $\begin{array}{l}\text { The function of the building on Suprapto street has a high level of } \\
\text { livability based on the results of observations and questionnaires that } \\
\text { show the diversity of building functions and is strengthened by the } \\
\text { intensity of respondents' visits that are quite diverse. }\end{array}$ \\
\hline Activity & & & $\begin{array}{l}\text { For activities there is a difference between existing and questionnaires } \\
\text { because based on observations in the field the activity conditions } \\
\text { on Suprapto street have a moderate level of livability seen from the } \\
\text { intensity of activities that occur in the afternoon to night at some } \\
\text { points, whereas based on the questionnaire the activity conditions on } \\
\text { Suprapto Road are low seen from the answers respondents who did } \\
\text { not often pass the street and the activities that were most carried out } \\
\text { by respondents were regular walking. This causes differences in the } \\
\text { results of the level of livability so that the final result of activity on } \\
\text { Suprapto street is moderate because it is judged from the significant } \\
\text { activities carried out by road users with diverse time and diverse } \\
\text { activities as well. }\end{array}$ \\
\hline Accessibility & & & $\begin{array}{l}\text { As for accessibility, it is still low due to the lack of vehicle parking } \\
\text { capacity and there is also no special lane for cyclists (non-motorized } \\
\text { vehicles) along Suprapto Road. }\end{array}$ \\
\hline Safety & & & $\begin{array}{l}\text { it is still low because there are still traffic conflicts within the area on the } \\
\text { pedestrian lane that have been functioned by shop owners and street } \\
\text { vendors so that they interfere with the safety of foot deterioration. }\end{array}$ \\
\hline $\begin{array}{l}\text { Environmental } \\
\text { quality }\end{array}$ & & & $\begin{array}{l}\text { For the quality of the environment is still low because of the lack of } \\
\text { vegetation along the pedestrian pathway which causes less shade } \\
\text { and there is still garbage on the edge of the pedestrian pathway } \\
\text { causing unpleasant odors. }\end{array}$ \\
\hline
\end{tabular}


Table 10. Dialogue on Theories of Livable City Walk Components

\begin{tabular}{|c|c|c|c|c|}
\hline Aspect & Component & Indicator & Existing & Questionnaire \\
\hline \multirow[t]{2}{*}{ Function } & Building & $\begin{array}{l}\text { Diversity of building } \\
\text { functions }\end{array}$ & $\begin{array}{l}\text { Commercial buildings, } \\
\text { mixed use, and public } \\
\text { facilities }\end{array}$ & $\begin{array}{l}\text { Shops, places to eat, and } \\
\text { public facilities }\end{array}$ \\
\hline & Open Space & $\begin{array}{l}\text { The connector of the } \\
\text { building masses and the } \\
\text { entertainment stage }\end{array}$ & $\begin{array}{l}2 \text { open space that is not } \\
\text { maintained and } 1 \text { open } \\
\text { space that is maintained }\end{array}$ & $\begin{array}{l}\text { Less open space along the } \\
\text { road }\end{array}$ \\
\hline \multirow[t]{3}{*}{ Activity } & Building & $\begin{array}{l}\text { Has a large capacity and } \\
\text { free parking lot in front of } \\
\text { the building }\end{array}$ & $\begin{array}{l}\text { Has a narrow parking and } \\
\text { a little capacity. There are } \\
\text { street vendors who sell in } \\
\text { front of the building }\end{array}$ & $\begin{array}{l}\text { Parking is adequate with a } \\
\text { little capacity but requires } \\
\text { a special parking space for } \\
\text { lots of capacity }\end{array}$ \\
\hline & $\begin{array}{l}\text { Pedestrian } \\
\text { Path }\end{array}$ & $\begin{array}{l}\text { availability of street } \\
\text { furniture, signage as } \\
\text { a clear marker, and } \\
\text { available pedestrian } \\
\text { paths }\end{array}$ & & $\begin{array}{l}\text { It has clear signs, street } \\
\text { signs, information boards. } \\
\text { Still lacking street furniture } \\
\text { along the road such as } \\
\text { seating and trash }\end{array}$ \\
\hline & Open Space & $\begin{array}{l}\text { Street Furniture } \\
\text { availability }\end{array}$ & $\begin{array}{l}\text { There is no street } \\
\text { furniture along the road } \\
\text { like a place to sit to rest. } \\
\text { Has clear signage, and } \\
\text { pedestrian paths are } \\
\text { available }\end{array}$ & Still lacking Street Furniture \\
\hline Accessibility & $\begin{array}{l}\text { Pedestrian } \\
\text { Path }\end{array}$ & $\begin{array}{l}\text { Quality Connectors and } \\
\text { Street Furniture }\end{array}$ & $\begin{array}{l}2 \text { open spaces don't have } \\
\text { street furniture and } 1 \\
\text { open space already has } \\
\text { street furniture }\end{array}$ & $\begin{array}{l}\text { Special lanes are needed } \\
\text { for cyclists, pedicabs and } \\
\text { pedestrians }\end{array}$ \\
\hline \multirow[t]{2}{*}{ Safety } & Building & Extensive setback & $\begin{array}{l}\text { Pedestrian path is still } \\
\text { disjointed and do not } \\
\text { have street furniture }\end{array}$ & $\begin{array}{l}\text { There is no shade } \\
\text { vegetation along the } \\
\text { pedestrian path }\end{array}$ \\
\hline & $\begin{array}{l}\text { Pedestrian } \\
\text { Path }\end{array}$ & $\begin{array}{l}\text { Have safeguards along } \\
\text { the pedestrian path and } \\
\text { there is no misuse of the } \\
\text { pedestrian path }\end{array}$ & Has a broad setback & Extensive setback \\
\hline $\begin{array}{l}\text { Environmental } \\
\text { quality }\end{array}$ & Building & Has a green line & $\begin{array}{l}\text { Misuse of land by street } \\
\text { vendors and vehicle } \\
\text { parking }\end{array}$ & $\begin{array}{l}\text { Misuse of land by street } \\
\text { vendors and vehicle } \\
\text { parking }\end{array}$ \\
\hline Aspect & Open Space & $\begin{array}{l}\text { Has shade and shade } \\
\text { vegetation }\end{array}$ & $\begin{array}{l}\text { Still lack of trees as a } \\
\text { shade along the road. }\end{array}$ & Shady \\
\hline
\end{tabular}

\section{Conclusions and Recommendations}

\section{Conclusion}

Livability Level of Suprapto Street If It Works As a Citywalk

From the results of the analysis and discussion it can be concluded that the level of livability of Suprapto Road is still low. This is seen from the results of the discussion that what affects the level of livability in suprapto roads is still low in accessibility, safety and environmental quality. These 3 variables have an important role in the comfort of activities on Suprapto Street. However, for the other 2 variables: Function and activity have a moderate level of livability this is because along Suprapto road which is dominated by commercial buildings and has several buildings with different functions so it forms a variety of activities at different times.

Factors That Influenced the Livable Citywalk on Suprpato Street

Factors that influence the livable City Walk on Suprapto Street can be seen from the relationship between physical aspects and nonphysical aspects. Based on the results of the analysis and discussion, it was found several factors from the physical aspects that influence the level of livability on Suprapto Street:

\section{Building Related Street Vendor Variables} Street vendors are the potential for the improvement of commercial functions in the Suprapto Street corridor. The activity of street vendors in the afternoon until the 
evening is the potential to increase the area's livestock in the afternoon until the evening. So that it is necessary to arrange and provide facilities in this case regional infrastructure.

2. Setback Related to Variable Parking, street Vendors, and Pedestrians

Street vendors are the potential for the improvement of commercial functions in the Suprapto Street corridor. The activity of street vendors in the afternoon until the evening is the potential to increase the area's livestock in the afternoon until the evening. So that it is necessary to arrange and provide facilities in this case regional infrastructure.

3. Buildings Related to Setback Variables Buildings with a regular setback reduce contrast in road space. One way to improve the quality of road space is to add setback contrast in the road space

4. Pedestrian Path Related to Pedestrian Variables

Misuse of pedestrian paths by shops, parking lots, and street vendors leads to reduced comfort and safety for pedestrians. The principles of safety, related to protection from traffic conflicts, comfort (Convenience), relating to the clarity of the path, the ease of going to one place, and pleasure, comfort relating to aspects physical aspects such as protection from the weather have not been met.

5. Street Furniture Associated with Pedestrians

Seating, standing, talking, playing, and gathering activities cannot be carried out by pedestrians due to the absence of adequate street furniture facilities which causes low livability of the area from social activities.

6. Signage Related to Pedestrian Variables and Vehicle Users

Most types of signage identification, convey information about the identity of a store. The side signage attached to the building with medium height makes it easy for pedestrians and vehicle users to get information

7. Vegetation Related to Pedestrians Vegetation on Surpapto Road is very lacking, causing low intensity of pedestrian activity. Vegetation is one of the elements in increasing the livability of an area, the more shade vegetation the higher the intensity of pedestrian activity in open spaces

\section{Recommendation}

\begin{tabular}{lll}
\hline $\begin{array}{l}\text { ROAD } \\
\text { BEARING }\end{array}$ & ROAD ROOM & PEDESTRIAN PATH \\
\hline $\begin{array}{l}\text { ROAD } \\
\text { BEARING }\end{array}$ & $\begin{array}{l}\text { Open Space as a link } \\
\text { between a series of } \\
\text { buildings and the plural } \\
\text { mosque }\end{array}$ & $\begin{array}{l}\text { - Placement of street } \\
\text { furniture in the } \\
\text { pedestrian path as a } \\
\text { pedestrian rest area. }\end{array}$ \\
& $\begin{array}{l}\text { (n) } \\
\text { The concept of utilizing } \\
\text { road space as an open } \\
\text { space/transit point }\end{array}$ & - Green line along the \\
pedestrian path
\end{tabular}

space/transit point

\section{Design \\ Recommendations}

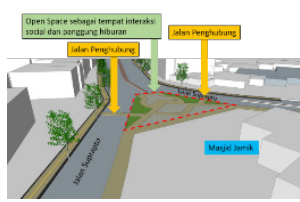

Design

Recommendations

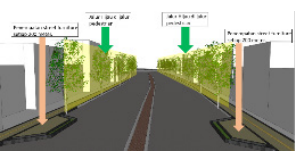

ROAD

Utilizing 2 nodes

as open space that

functions to connect the building mass and the entertainment stage.

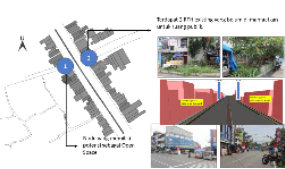

- Street furniture in the pedestrian lane

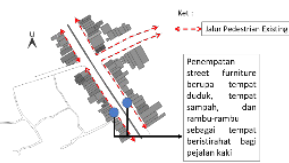

Green line along the pedestrian path

Existing Road Cut 2

Node Design

Recommendations 1
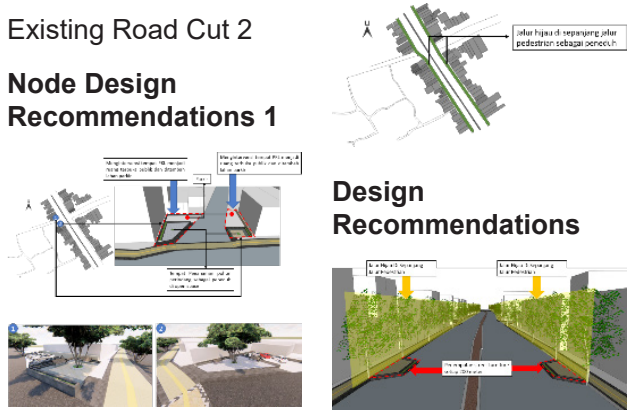

Design

Recommendations

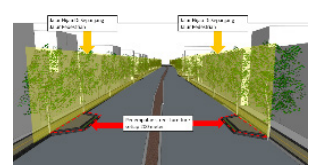

Node Design

Recommendations 2

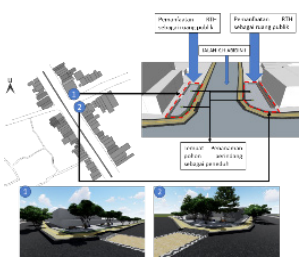




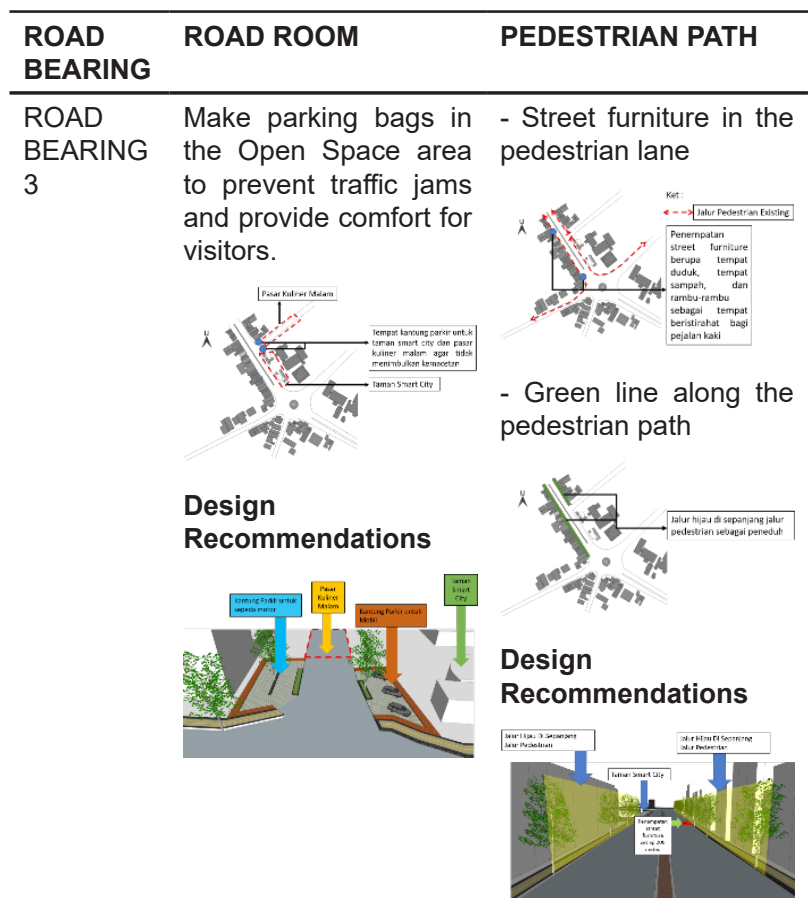

\section{Reference}

Anonimous. (1998). Portland Pedestrian Guide. June. 3p.

Appleyard, D. (1981). Livable Street. University of California Press : Berkeley, USA, 234.

Booth, N.K. (1983). Basic Elements Of Landscape Architectural Design. Illinois: Waveland Press

Beng-hunt and Noman, E. (1992). Public Space;Design, Use and Management, Singapore University Press.

Caliandro, V. (1978). On streets. Edited by Standford Anderson. The MIT Perss, England.

Carr, S., et al. (1992) Public Space, Cambridge University Press, Cambridge

Choudhury, A. (2008). Identifying Criteria That Sustain Livable Streets. Master's Report for Master in Architecture with a Concentration in Urban Desig. University of Arizona, Tucson. Arizona.openrepository. com/arizona/.../azu_etd_...(diakses pada 10 desember 2018, pk 22.32)

Aditya, W. F. (2006). Citywalk - artikel IAI

GLC Study, 1980, An Introdoction to Housing Layout. The Architecture Press, London.

Jacobs, A. B. (1995). Great Streets, MIT Press Cabridge Press.

Montgomery, J. (1998). Making a City: Urbanity, Vitality and Urban Design. Journal of Urban Design.

Moudon. (1987). Public Street and Square. Van
Nostrand Reinhold Company, New York. Office of Transportation Engineering and Development. (1998). Portland Pedestrian Design Guide. Portland: The Pedestrian Transportation Program

Noeng, M. (1998). Metode Penelitian Kualitatif, Yogyakarta: Rake serasin.

Rossi, A. (1992). The Architecture of The City. 